\title{
Tutorial Praktikum Kalorimeter Berbasis Augmented Reality Dan Metode Mamdani
}

\author{
Gita Cahyani Lestari ${ }^{1}$, Sri Supatmi ${ }^{2}$, Usep Mohammad Ishaq ${ }^{3}$ \\ 1,3)Program Studi Sistem Komputer, Fakultas Teknik dan Ilmu Komputer, Universitas Komputer Indonesia \\ Jl. Dipati Ukur No. 112 - 116, Bandung, Indonesia 40132 \\ 2)Program Studi Magister Sistem Informasi, Fakultas Pascasarjana, Universitas Komputer Indonesia \\ Jl. Dipati Ukur No. 112-116, Bandung, Indonesia 40132 \\ *email: gitacahyanilestari@mahasiswa.unikom.ac.id
}

(Naskah masuk: 30 Agustus 2020; diterima untuk diterbitkan: 30 September 2020)

\begin{abstract}
ABSTRAK - Proses pembelajaran harus dikemas dengan menarik agar peserta didik termotivasi untuk belajar. Maka dari itu, diperlukan media interaktif yang menunjang proses pembelajaran didukung oleh alat-alat berupa media yang menarik seperti teknologi Augmented Reality. Teknologi ini banyak digunakan untuk industri hiburan karena dapat memberikan kesan nyata kepada penggunanya sehingga dapat membantu meningkatkan motivasi para peserta didik dalam belajar. Pada topik ini, penelitian dikhususkan pada pembuatan Augmented Reality tentang tutorial praktikum fisika dasar modul kalorimeter pada jurusan Sistem Komputer di Universitas Komputer Indonesia yang berbasis Android. Aplikasi ini menyajikan pengenalan alat dan bahan praktikum serta langkah-langkah praktikum. Selain itu, dapat melakukan pemrosesan data praktikum menggunakan metode fuzzy Mamdani karena dalam melakukan pengukuran sering terjadi kesalahan yang mengakibatkan hasilnya tidak tepat sama dengan data kalor jenis zat sehingga kesulitan dalam menentukannya. Hasil pengujian menunjukkan sebesar 76,25\% mempermudah praktikan untuk memahami suatu materi praktikum kalorimeter, dan 80\% mempermudah pemrosesan data praktikum serta diperoleh error data sebesar 0,0000005 menggunakan metode fuzzy mamdani sehingga dapat digunakan untuk penentuan kalor jenis.
\end{abstract}

Kata Kunci : Augmented Reality, Kalorimeter, Fuzzy Mamdani, Fisika Dasar, Praktikum

\section{Calorimeter Practicum Tutorial Of Augmented Reality And Mamdani Method}

\begin{abstract}
The learning process must be attractively packaged to motivate the students to learn. Therefore, it needed an interactive media that supports the learning process supported by new tools such as Augmented Reality technology. This technology is widely used for the entertainment industry because it can give a real impression to its users to help increase the motivation of students in learning. This research was making Augmented Reality about the basic physics practice tutorial on the calorimeter module in the Department of Computer Systems at the Indonesian Computer University based on Android. This application presents an introduction to practical tools and materials as well as practical steps. Also, the data of practicum can be done by employing the Mamdani fuzzy method due to assessments are often carried out relating to the right data with the type of substance's heat data, making it difficult to determine. The results show that $76.25 \%$ makes it easier for the practitioner to understand a calorimeter practicum material, and $80 \%$ makes it easier for the practicum data, then obtain a data error rate of 0.0000005 using the Mamdani fuzzy method to determine the specific heat.
\end{abstract}

Keywords - Augmented Reality, Calorimeter, Fuzzy Mamdani, Basic Physics, Practicum

\section{Pendahuluan}

Pendidikan merupakan suatu faktor yang mempengaruhi kemajuan bangsa [1]. Pendidikan diwujudkan dalam suatu kegiatan pembelajaran untuk mengembangkan potensi diri peserta didik salah satunya adalah metode praktikum. Metode praktikum menyajikan materi melalui pengamatan dan percobaan menggunakan alatalat praktikum [2]. Mata kuliah fisika dasar pada 
perguruan tinggi adalah ilmu yang lebih mudah dipahami dengan praktik sehingga tidak bisa dipelajari dari sisi teori saja. Bahan ajar materi praktikum ini masih kurang variatif karena hanya menyajikan dua media, yaitu gambar dan teks. Akibatnya, praktikan merasa kesulitan dalam mempelajari dan memahami materi praktikum sehingga membutuhkan imajinasi yang tinggi untuk dapat memahami materi tersebut khususnya modul kalorimeter. Oleh karena itu, kemampuan praktikan harus ditingkatkan melalui penggunaan beberapa indra dengan memuat penggunaan multimedia. Dalam praktikum modul kalorimeter, praktikan akan diminta untuk mengukur dan menghitung kalor jenis dari suatu zat yang diberikan di laboratorium dengan menggunakan alat kalorimeter. Kalorimeter digunakan untuk pencampuran dua zat atau lebih pada suatu alat berbentuk wadah yang berlangsung dalam keadaan ideal di mana keadaan ini tidak memungkinkan adanya interaksi antara zat lain dengan sistem pencampuran tersebut [3]. Hasil yang diperoleh tersebut dicocokkan dengan tabel kalor jenis zat untuk menentukan kalor jenis. Permasalahan yang sering muncul dalam penentuan kalor jenis adalah hasil yang diperoleh tidak tepat sama dengan data kalor jenis zat sehingga kesulitan dalam menentukannya.

Berdasarkan permasalahan tersebut, perlu sebuah media interaktif yaitu penggunaan teknologi Augmented Reality. Teknologi ini dapat membuat praktikan melakukan simulasi mirip dengan sebenarnya. Untuk menampilkan objek 3D, kamera akan membaca kemudian melacak marker (penanda) menggunakan algoritma FAST Corner yang bekerja menurunkan tingkat akurasi pada deteksi sudut [4],[5]. Pada penerapan Augmented Reality ini menggunakan metode Marker-Based Tracking berupa marker objek dua dimensi yang memiliki pola ilustrasi putih dan hitam persegi dengan latar belakang putih dan batas hitam tebal yang nantinya dibaca oleh media kamera [6],[7],[8].

Selanjutnya, dalam menentukan kalor jenis zat menggunakan metode Fuzzy Mamdani. Metode ini akan memberikan toleransi terhadap nilai, apabila terjadi perbedaan sedikit pada suatu nilai tersebut tidak akan memberikan perubahan yang signifikan [9],[10]. Dengan demikian, akan mempermudah dalam menentukan jenis kalornya walaupun hasil yang didapat tidak sama persis.

Penelitian sebelumnya yang telah dilakukan oleh Selvia Lorena Br. Ginting, dan Fauzi Sofyan [6] tentang "Aplikasi Pengenalan Alat Musik Tradisional Indonesia Menggunakan Metode Based Marker Augmented Reality Berbasis Android". Hasil yang didapatkan bahwa teknologi Augmented Reality dapat memainkan alat musik tradisional seperti pada alat musik yang sebenarnya. Kemudian penelitian oleh Sigit Wasista, Setiawardhana, dkk [11] tentang "Aplikasi Augmented Reality Untuk Pengenalan Jaringan Komputer Berbasis Android Sebagai Media Pembelajaran Interaktif" menggunakan metode based marker Augmented Reality. Hasil yang didapatkan bahwa Augmented Reality dapat mengurangi rasa jenuh dalam proses pembelajaran. Dan penelitian oleh Irfan Dwiguna Sumitra dan Sri Supatmi [12] "Mamdani Fuzzy Inference System Using Three Parameters For Flood Disaster Forecasting In Bandung Region". Hasil yang didapatkan dengan sistem inferensi fuzzy menerapkan algoritma Mamdani di Matlab telah berhasil meramalkan banjir untuk menginformasikan keadaan di suatu daerah di Provinsi Jawa Barat dan menyajikan akurasi tinggi untuk memutuskan keadaan peramalan di suatu wilayah.

Berangkat dari beberapa peneliti sebelumnya, peneliti bertujuan membuat aplikasi teknologi Augmented Reality untuk tutorial praktikum fisika dasar modul kalorimeter dan penentuan kalor jenis menggunakan metode Fuzzy Mamdani pada jurusan sistem komputer di Universitas Komputer Indonesia berbasis Android. Selain itu, aplikasi ini menyajikan pengenalan alat-alat praktikum, langkah-langkah dalam praktikum, dan pemrosesan data praktikum sehingga praktikan dapat membandingkan hasil perhitungan secara matematis dengan aplikasi yang ada di Android. Aplikasi ini diharapkan dapat mempermudah asisten dosen untuk menerangkan suatu materi sehingga praktikan dapat memahami teori, menyiapkan alat dan bahan, memasang serta menggunakan alat praktikum menggunakan media yang menyenangkan.

\section{METODE DAN BAHAN}

\section{Metode Penelitian}

Pada metode penelitian ini menggunakan metode waterfall yang terdiri dari enam tahapan [13], yaitu:

1. Analisis Kebutuhan

Pada tahap ini, menganalis seluruh kebutuhan dari perangkat lunak yang akan dibangun.

2. Perancangan Sistem

Studi literatur yaitu menentukan software yang digunakan dalam pembangunan sistem. Tools yang digunakan yaitu blender versi 2.82 untuk membuat objek 3D beserta informasinya, unity versi 2019.3.13f sebagai 
application build dan vuforia sdk sebagai library augmented reality. Untuk antarmuka berbasis Android menggunakan pemrograman berorientasi objek menggunakan UML.

3. Kode Program

Kode program yaitu melakukan penerjemahan dari perancangan menjadi bahasa pemrograman $\mathrm{C \#}$.

4. Pengujian

Sistem yang telah dibuat akan diuji menggunakan pengujian alpha metode blackbox untuk mengetahui apakah sesuai antara perangkat lunak dengan perancangan yang diinginkan. Kemudian, pengujian akurasi bertujuan untuk mengetahui akurasi perhitungan dari penerapan metode fuzzy mamdani. Selanjutnya pengujian beta untuk mengetahui tingkat kepuasan pengguna terhadap aplikasi yang telah dibangun. Sedangkan pengujian marker untuk mengetahui marker yang dibuat apakah sudah berjalan dengan baik.

5. Analisa dan kesimpulan, yaitu analisa yang dilakukan dari pengujian sistem dalam mengambil beberapa informasi dari penelitian ini. Data yang sudah diambil dalam tahap pengujian akan diolah agar didapatkan kesimpulan.

Dalam penelitian ini, melakukan proses mengumpulkan data sebagai berikut:

1. Studi literatur, yaitu mempelajari materi yang berkaitan dengan topik penelitian dari internet, buku maupun jurnal.

2. Studi lapangan, melakukan observasi ke laboratorium fisika dasar di Universitas Komputer Indonesia untuk mengamati proses pembelajaran praktikum kalorimeter dan memperoleh data praktikum sehingga dapat divisualisasikan menjadi objek 3D.

3. Wawancara, pada penelitian ini melakukan wawancara kepada asisten dosen lab fisika dasar tentang ke-efektif-an aplikasi tutorial praktikum kalorimeter. Wawancara ini bertujuan mendapatkan hasil pengujian beta.

4. Survei, pada penelitian ini untuk mengetahui ke-efektif-an aplikasi yang dibangun maka menyediakan kuesioner kepada praktikan yang telah mengambil mata kuliah fisika dasar. Kuesioner tersebut diberikan kepada 20 mahasiswa/i Program Studi Sistem Komputer di Universitas Komputer Indonesia. Survei ini bertujuan mendapatkan hasil pengujian beta.

\section{Pemodelan Sistem}

Unified Modeling Language (UML) merupakan pemodelan berupa bahasa yang dipakai dalam membangun, mendokumentasikan, dan menspesifikasikan suatu perangkat lunak [6],[14]. Perancangan aplikasi ini sebagai berikut:

A. Use Case Diagram

Use case menggambarkan interaksi antara seorang aktor dengan sistem [4]. Berikut Use Case Diagram pada aplikasi teknologi Augmented Reality untuk tutorial praktikum kalorimeter dan penentuan kalor jenis menggunakan metode fuzzy mamdani tercantum pada gambar berikut:

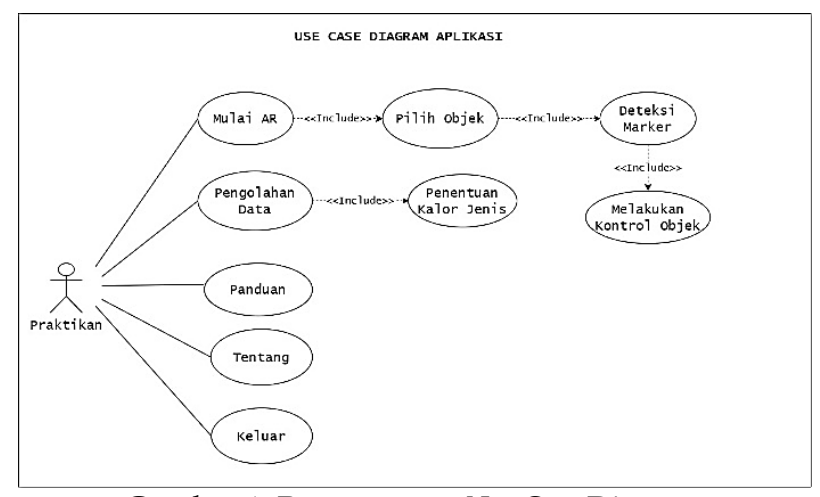

Gambar 1. Perancangan Use Case Diagram

Pada gambar 1 terdapat satu aktor dan delapan Use Case yang dibutuhkan dalam sistem Aktor tersebut adalah praktikan. Sementara Use Case pada sistem ini terdiri dari Mulai AR, Pilih Objek, Deteksi Marker, Melakukan Kontrol Objek, Pengolahan Data, Penentuan Kalor Jenis, Panduan, Tentang, dan Keluar.

\section{Definisi Aktor}

Setiap aktor yang terdapat pada sistem akan dideskripsikan berdasarkan aktivitas yang dapat dilakukannya dalam sistem. Definisi aktor pada aplikasi ini dapat dilihat pada table 1 .

Tabel 1. Definisi Aktor

\begin{tabular}{lllr}
\hline No & Use Case & \multicolumn{1}{c}{ Deskripsi } \\
\hline 1. & Praktikan & Pengguna aplikasi AR, \\
& & melakukan pilih objek, deteksi \\
& marker, mengolah data praktikum, \\
& melihat panduan aplikasi, melihat \\
& informasi pembuat aplikasi dan \\
& keluar dari aplikasi. \\
\hline
\end{tabular}

\section{Definisi Use Case}

Setiap Use Case yang terdapat pada gambar 3 akan dideskripsikan berupa penjabaran aktivitas yang terjadi pada sistem. Pada Tabel 2 merupakan definisi Use Case pada system. 
Tabel 2. Definisi Use Case

\begin{tabular}{|c|c|c|}
\hline No & Use Case & Deskripsi \\
\hline 1. & Mulai AR & $\begin{array}{l}\text { Menu untuk menampilkan } \\
\text { halaman tutorial praktikum } \\
\text { berdasarkan objek dan dapat } \\
\text { dipilih oleh praktikan }\end{array}$ \\
\hline $2 .$. & Pilih Objek & $\begin{array}{l}\text { Proses menampilkan menu yang } \\
\text { dapat dipilih praktikan sesuai } \\
\text { objek }\end{array}$ \\
\hline 3. & $\begin{array}{l}\text { Deteksi } \\
\text { Marker }\end{array}$ & $\begin{array}{l}\text { Proses di mana kamera akan } \\
\text { mendeteksi marker berdasarkan } \\
\text { marker yang dipilih oleh praktikan }\end{array}$ \\
\hline 4. & $\begin{array}{l}\text { Melakukan } \\
\text { Kontrol } \\
\text { Objek }\end{array}$ & $\begin{array}{l}\text { Proses melakukan fungsi Zoom In, } \\
\text { Zoom Out dan Rotasi terhadap } \\
\text { Objek 3D. }\end{array}$ \\
\hline 5. & $\begin{array}{l}\text { Pengolahan } \\
\text { Data }\end{array}$ & $\begin{array}{l}\text { Menampilkan halaman } \\
\text { pengolahan data praktikum }\end{array}$ \\
\hline 6. & $\begin{array}{l}\text { Penentuan } \\
\text { Kalor Jenis }\end{array}$ & $\begin{array}{l}\text { Proses menentukan kalor jenis } \\
\text { menggunakan metode fuzzy } \\
\text { Mamdani }\end{array}$ \\
\hline 7. & Panduan & $\begin{array}{l}\text { Menampilkan informasi cara } \\
\text { menggunakan aplikasi }\end{array}$ \\
\hline 8. & Tentang & $\begin{array}{l}\text { Menampilkan identitas dan versi } \\
\text { aplikasi dari developer }\end{array}$ \\
\hline 9. & Keluar & $\begin{array}{l}\text { Merupakan tombol keluar untuk } \\
\text { keluar dari aplikasi }\end{array}$ \\
\hline
\end{tabular}

\section{B. Class Diagram}

Class Digram merupakan diagram yang menampilkan beberapa kelas beserta hubungan sistem [14]. Berikut class diagram pada aplikasi.

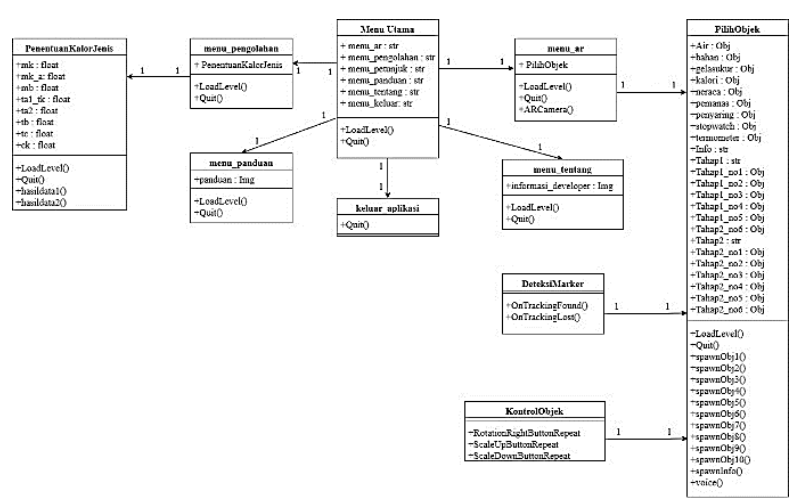

Gambar 2. Class Diagram

\section{Perancangan Sistem}

Perancangan sistem bertujuan untuk mempermudah dalam pembuatan aplikasi. Adapun perancangan sistem pada aplikasi sebagai berikut:

A. Komponen

Untuk membangun aplikasi ini dibutuhkan komponen yang menunjung pembangunan sistem.

Tabel 3. Kebutuhan Perangkat Lunak

\begin{tabular}{lll}
\hline No & $\begin{array}{c}\text { Perangkat } \\
\text { Lunak }\end{array}$ & \multicolumn{1}{c}{ Keterangan } \\
\hline 1. & Windows & $\begin{array}{l}\text { Sebagai sistem operasi dari } \\
\text { komputer yang digunakan. }\end{array}$ \\
\hline
\end{tabular}

\begin{tabular}{|c|c|c|}
\hline No & $\begin{array}{l}\text { Perangkat } \\
\text { Lunak }\end{array}$ & Keterangan \\
\hline 2. & Unity 3D & $\begin{array}{l}\text { Digunakan untuk membuat } \\
\text { media pembelajaran } \\
\text { praktikum kalorimeter. }\end{array}$ \\
\hline 3. & Blender & $\begin{array}{l}\text { Digunakan untuk membuat } \\
\text { objek 3D praktikum } \\
\text { kalorimeter. }\end{array}$ \\
\hline 4. & $\begin{array}{l}\text { Vuforia } \\
\text { SDK }\end{array}$ & $\begin{array}{l}\text { Digunakan untuk library } \\
\text { Augmented Reality. }\end{array}$ \\
\hline 5. & $\begin{array}{l}\text { SDK } \\
\text { Android }\end{array}$ & $\begin{array}{l}\text { Digunakan untuk membuat } \\
\text { aplikasi mampu berjalan } \\
\text { pada platform Android. }\end{array}$ \\
\hline 6. & JDK & $\begin{array}{l}\text { Digunakan untuk logika } \\
\text { source code dalam } \\
\text { pembuatan input field pada } \\
\text { menu pengolahan data. }\end{array}$ \\
\hline 7. & StarUML & $\begin{array}{l}\text { Digunakan untuk membuat } \\
\text { use case diagram, activity } \\
\text { diagram,sequence diagram, } \\
\text { dan class diagram. }\end{array}$ \\
\hline
\end{tabular}

B. Perancangan Data

Perancangan data adalah suatu proses menentukan kebutuhan data beserta isinya untuk mendukung rancangan sistem.

Tabel 4. Perancangan Data

\begin{tabular}{lll}
\hline No & \multicolumn{1}{c}{ Field Name } & Type \\
\hline 1. & Marker & Img \\
2. & $\begin{array}{l}\text { Alat dan Bahan Praktikum, Tahap 1, } \\
\text { dan Tahap II }\end{array}$ & .blend \\
3. & Informasi & Img, \\
& & Audio \\
4. & Tombol Menu & Img \\
5. & Tampilan Panduan & Img \\
6. & Tampilan Tentang & Img \\
7. & Data Praktikum & Float \\
8. & Input Fuzzy Mamdani & Float \\
9. & Output Fuzzy Mamdani & Teks \\
\hline
\end{tabular}

C. Gambaran Umum Sistem

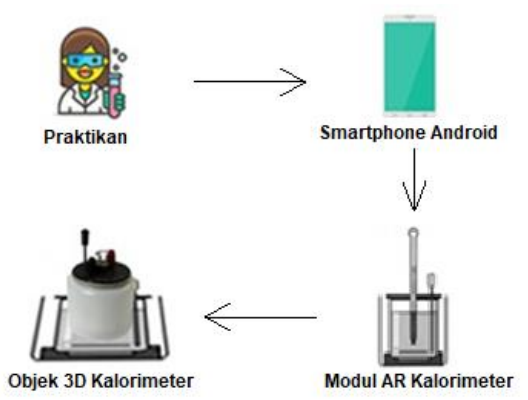

Gambar 3. Gambaran Umum Sistem

Berikut keterangan dari gambar:

1. Praktikan, sebagai pengguna yang sedang mengambil mata kuliah praktikum fisika dasar modul kalorimeter.

2. Smartphone Android sebagai pengindaian terhadap marker yang sudah disediakan. 
3. AR modul kalorimeter sebagai penanda (marker) yang sudah disediakan.

4. Objek 3D Kalorimeter sebagai objek yang ditampilkan di atas marker sehingga praktikan dapat berinteraksi dengan objek. Setelah itu praktikan dapat memilih beberapa opsi seperti informasi objek 3D, rotasi, perbesar atau perkecil objek 3D.

D. Perancangan Fuzzy Mamdani

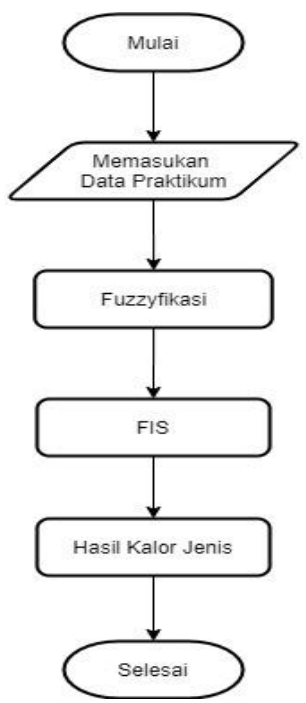

Gambar 4. Flowchart Fuzzy Mamdani

Gambar 4 menjelaskan tentang sistem penentuan kalor jenis menggunakan metode fuzzy Mamdani. Dalam penelitian ini diasumsikan bahwa $\mathrm{Ck}$, dan $\mathrm{Cb}$ merupakan nilai yang nantinya akan dicocokkan dengan data kalor jenis zat untuk memperkirakan jenis zat yang digunakan pada saat praktikum. Kedua parameter tersebut digunakan sebagai inputan terhadap sistem yang dibangun.

1. Praktikan diminta untuk mengisi data praktikum sehingga mendapatkan nilai $\mathrm{Ck}$ dan $\mathrm{Cb}$.

2. Fuzzifikasi

Dalam penelitian ini terdapat empat variabel, yaitu 2 variabel input terdiri dari Variabel $\mathrm{Ck}$ memiliki nilai himpunan fuzzy 0,216-0,230, Variabel $\mathrm{Cb}$ memiliki nilai himpunan fuzzy yaitu 0,189-0,241, 0,137-0,183, dan 0,097-0,129. Sedangkan untuk output memiliki 2 variabel output yaitu Variabel Kalor Jenis Kalorimeter yang memiliki nilai himpunan yaitu Aluminium, Variabel Kalor Jenis Zat memiliki nilai himpunan yaitu, Aluminium, Besi, dan Kaca.

3. Penentuan fuzzy rule

Pada Tahap ini Variabel tersebut diubah ke dalam bentuk himpunan fuzzy. Selanjutnya, dibentuk aturan yang sesuai untuk penentuan kalor jenis.

Pada kasus ini terdapat 4 rules sebagai berikut:

1. $\mathrm{R} 1=$ If $\mathrm{Ck} \geq 0,216$ or $\mathrm{Ck} \leq 0,230$ Then Kalor jenis kalorimeter $=$ "Aluminium"

2. $\mathrm{R} 2=$ If $\mathrm{Cb} \geq 0,189$ or $\mathrm{Cb} \leq 0,241$ Then Kalor jenis Zat $=$ "Aluminium"

3. $\mathrm{R} 3=$ If $\mathrm{Cb} \geq 0,137$ or $\mathrm{Cb} \leq 0,183$ Then Kalor jenis Zat $=$ "Kaca"

4. $\mathrm{R} 4=$ If $\mathrm{Cb} \geq 0,097$ or $\mathrm{Cb} \leq 0,129$ Then Kalor jenis Zat $=$ "Besi

\section{Rancangan Aplikasi}

Perancangan aplikasi bertujuan memberikan gambaran terkait aplikasi yang akan dibangun. Berikut adalah perancangan aplikasi yang akan dibangun.
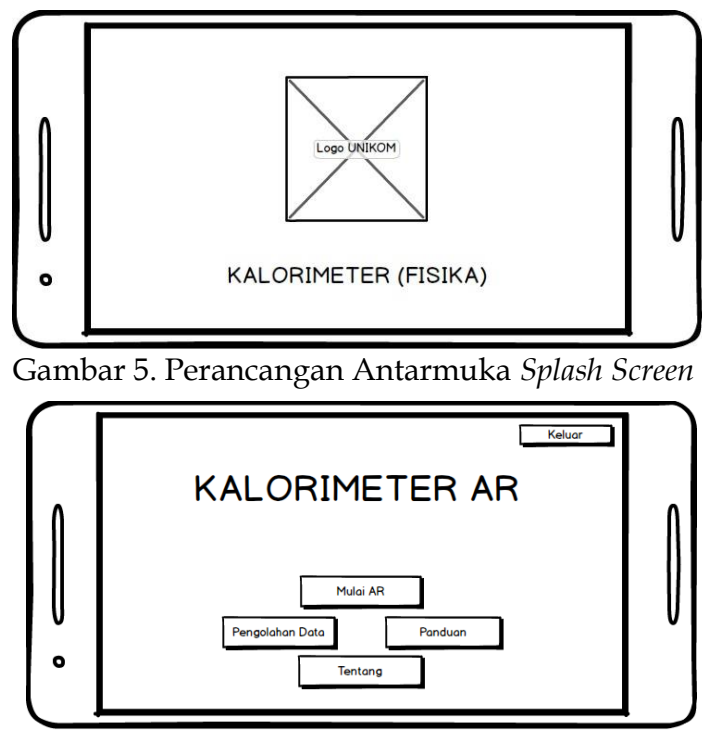

Gambar 6. Perancangan Antarmuka Halaman Utama

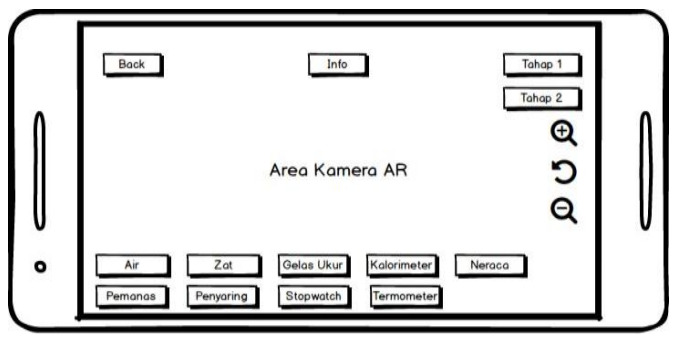

Gambar 7. Perancangan Antarmuka Mulai AR Alat dan Bahan

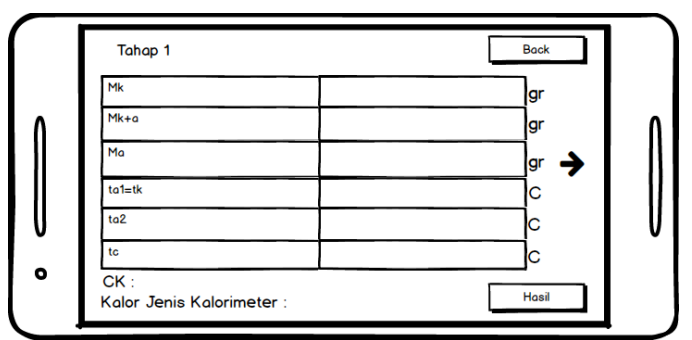

Gambar 8. Perancangan Antarmuka Pengolahan Data Tahap I 


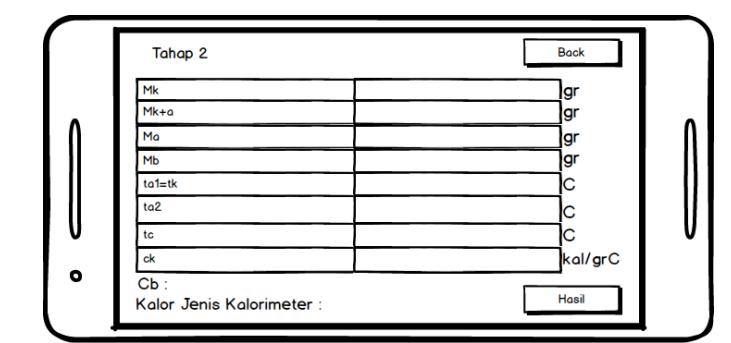

Gambar 9. Perancangan Antarmuka Pengolahan Data Tahap II

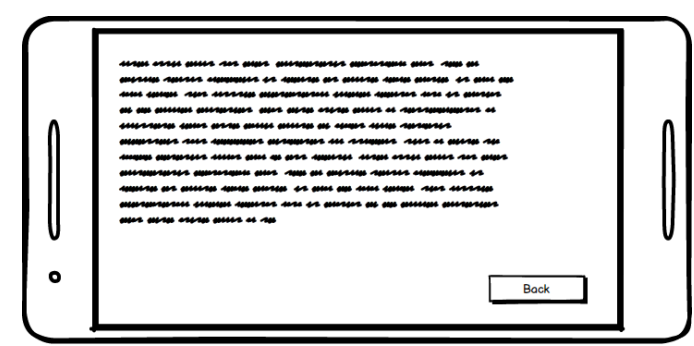

Gambar 10. Perancangan Antarmuka Menu Panduan

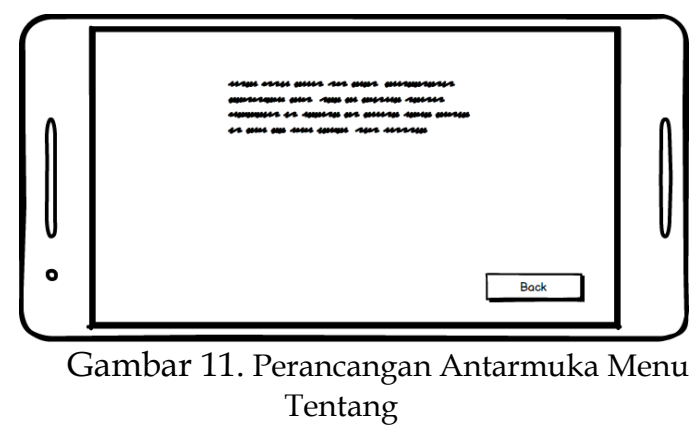

\section{HASIL DAN PEMBAHASAN}

Hasil dan pembahasan sistem yang telah dibangun sebagai berikut:

\section{Tampilan Layar Aplikasi}

\section{A. Tampilan Splash Screen}

Tampilan ini merupakan tampilan pertama yang ditampilkan ketika praktikan memilih mulai aplikasi.

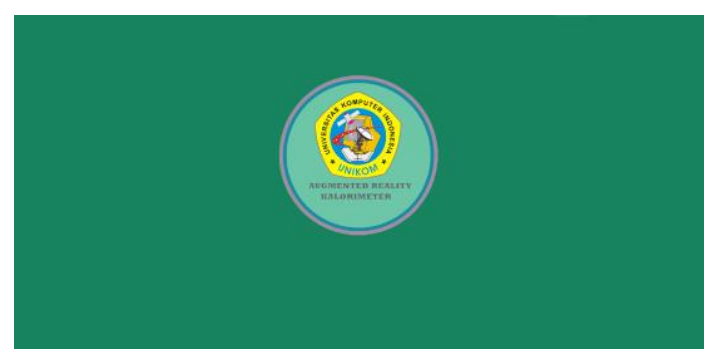

Gambar 12. Tampilan Splash Screen

\section{B. Tampilan Menu Utama}

Tampilan menu ini adalah halaman utama aplikasi yang terdapat beberapa tombol, diantaranya tombol menu mulai $\mathrm{AR}$, tombol menu pengolahan data, tombol menu panduan, tombol menu tentang, dan tombol keluar.

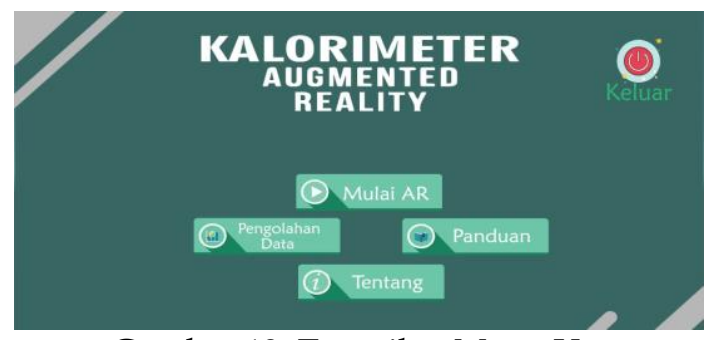

Gambar 13. Tampilan Menu Utama

C. Tampilan Menu Mulai AR

Pada gambar 14 merupakan tampilan Mulai AR, di mana akan mengaktifkan kamera AR untuk melakukan deteksi marker sehingga dapat menampilkan objek 3D dan informasi alat dan bahan praktikum.

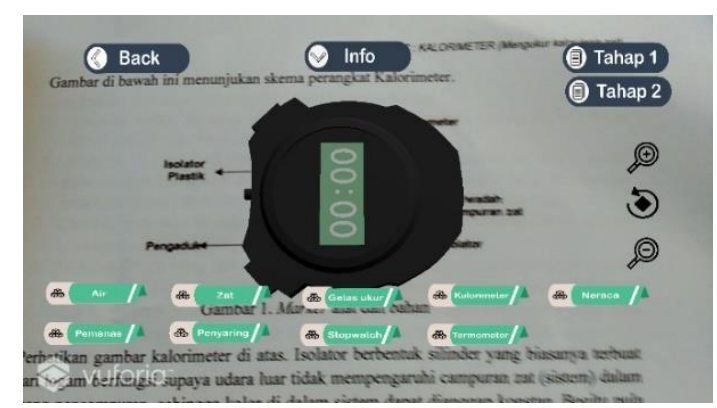

Gambar 14. Tampilan Menu Mulai AR Alat dan Bahan

Pada gambar 15 menampilkan halaman Mulai AR tahap I. Pada halaman ini untuk menampilkan langkah-langkah praktikum dan informasi tahap I.

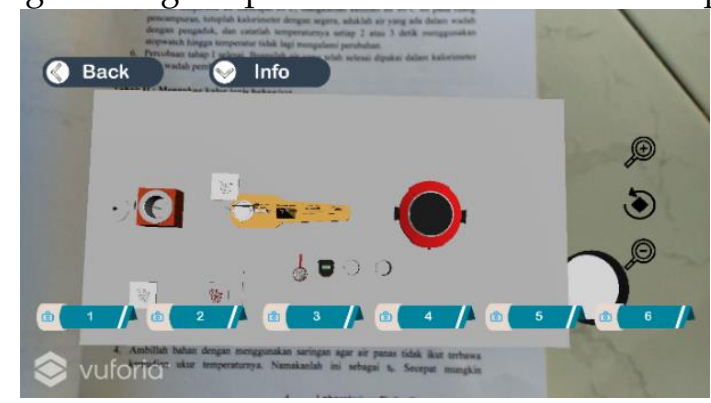

Gambar 15. Tampilan Mulai AR Tahap 1

Pada gambar 16 menampilkan halaman Mulai AR jenis bahan. Pada halaman ini untuk menampilkan pilihan jenis bahan yang akan digunakan pada praktikum tahap II.

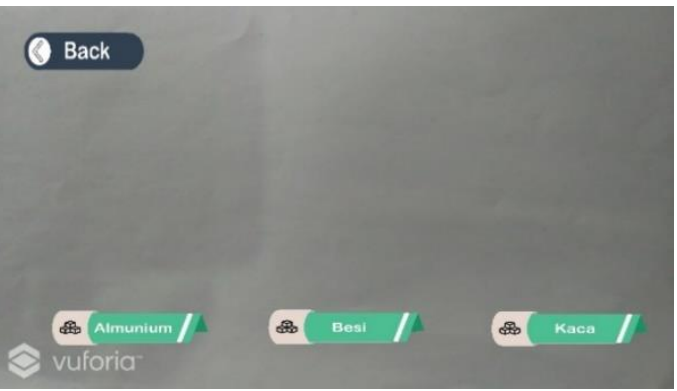


Gambar 16. Mulai AR Jenis Bahan

Pada gambar 17 menampilkan halaman Mulai AR tahap II. Pada halaman ini untuk menampilkan langkah-langkah praktikum dan informasi tahap II.

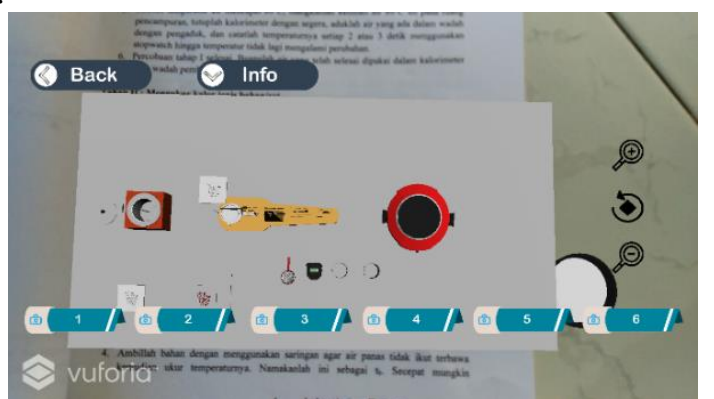

Gambar 17. Tampilan Antarmuka Mulai AR Tahap II

D. Tampilan Menu Pengolahan Data

Pada gambar 18 merupakan tampilan menu Pengolahan Data Praktikum tahap 1 untuk penentuan kalor kalor jenis kalorimeter menggunakan metode fuzzy mamdani.

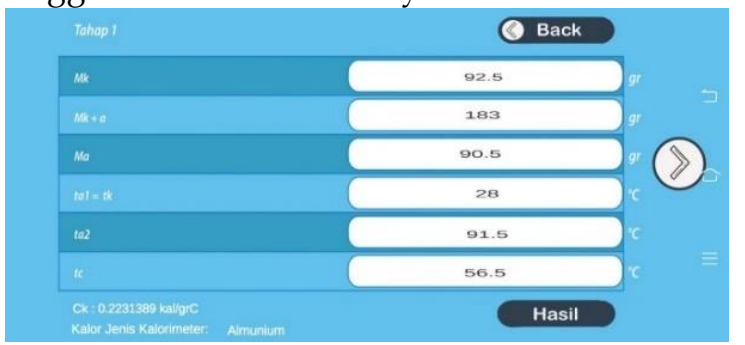

Gambar 18. Tampilan Pengolahan Data Tahap 1

Pada gambar 19 merupakan tampilan menu Pengolahan Data Praktikum tahap II untuk penentuan kalor kalor jenis zat menggunakan metode fuzzy mamdani.

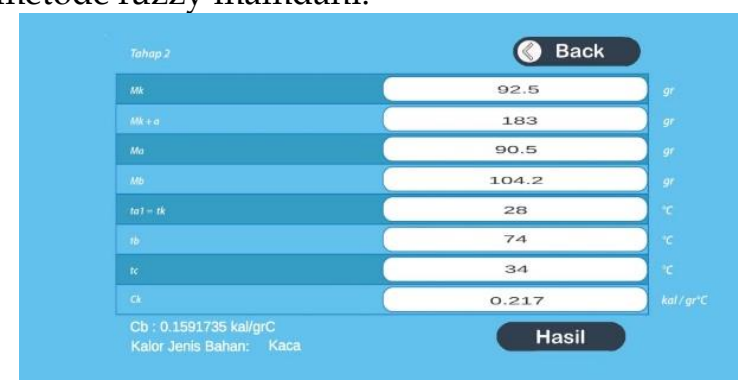

Gambar 19. Tampilan Pengolahan Data Tahap II

E. Tampilan Menu Panduan

Pada gambar 20 tampilan menu panduan yang berisi penjelasan bagaimana caranya melakukan scan marker AR.

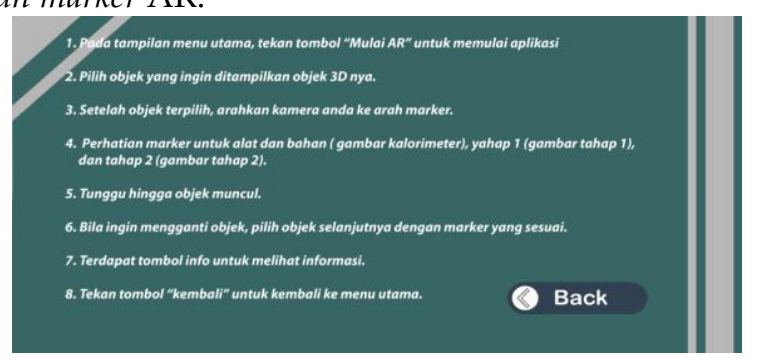

Gambar 20.Tampilan Menu Panduan
F. Tampilan Menu Tentang

Tampilan menu tentang yang berisi penjelasan tentang developer.

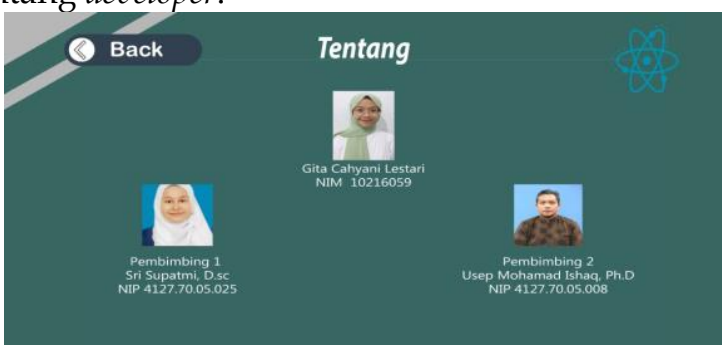

Gambar 21. Tampilan Menu Tentang

\section{Pengujian Aplikasi}

Pengujian sistem dilakukan untuk menemukan kesalahan/kekurangan pada perangkat lunak yang telah dibangun [5],[15]. Terdapat beberapa pengujian sebagai berikut:

A. Pengujian Alpha

Pada pengujian ini menggunakan metode BlackBox bertujuan untuk mengetahui bahwa program pada aplikasi ini menghasilkan output yang sesuai dengan rancangan. Berikut ini hasil pengujian alpha yang telah dilakukan. Tabel 5. Skor Pernyataan Responden.

\begin{tabular}{cc} 
Tabel 6. Skor Pernyataan Responden \\
\hline $\begin{array}{c}\text { Tingkat } \\
\text { Kepuasan }\end{array}$ & Skala \\
\hline SS & 4 \\
S & 3 \\
TS & 2 \\
STS & 1 \\
\hline
\end{tabular}

Tabel 7. Hasil Pengujian Alpha

\begin{tabular}{|c|c|c|c|}
\hline No & $\begin{array}{l}\text { Komponen } \\
\text { yang Diuji }\end{array}$ & Skenario Uji & Ket \\
\hline \multirow[t]{4}{*}{1.} & $\begin{array}{l}\text { Menu } \\
\text { Utama }\end{array}$ & Tekan Tombol Mulai AR & Berhasil \\
\hline & & $\begin{array}{l}\text { Tekan Tombol } \\
\text { Pengolahan Data }\end{array}$ & Berhasil \\
\hline & & Tekan Tombol Panduan & Berhasil \\
\hline & & Tekan Tombol Tentang & Berhasil \\
\hline \multirow[t]{8}{*}{2.} & $\begin{array}{l}\text { Menu } \\
\text { Mulai AR }\end{array}$ & $\begin{array}{lll}\text { Tekan Tombol } & \text { Objek } \\
\text { Alat dan } & \text { Bahan } \\
\text { Praktikum } & \end{array}$ & Berhasil \\
\hline & & Tekan Tombol Zoom In & Berhasil \\
\hline & & Tekan Tombol Zoom Out & Berhasil \\
\hline & & Tekan Tombol Rotasi & Berhasil \\
\hline & & Tekan Tombol Info & Berhasil \\
\hline & & Tekan Tombol Tahap 1 & Berhasil \\
\hline & & Tekan Tombol Tahap II & Berhasil \\
\hline & & Tekan Tombol Back & Berhasil \\
\hline \multirow[t]{6}{*}{3.} & $\begin{array}{l}\text { Halaman } \\
\text { Tahap } 1\end{array}$ & Tekan Tombol Nomor & Berhasil \\
\hline & & Tekan Tombol Zoom In & Berhasil \\
\hline & & Tekan Tombol Zoom Out & Berhasil \\
\hline & & Tekan Tombol Rotasi & Berhasil \\
\hline & & Tekan Tombol Info & Berhasil \\
\hline & & Tekan Tombol Back & Berhasil \\
\hline
\end{tabular}




\begin{tabular}{|c|c|c|c|}
\hline No & $\begin{array}{l}\text { Komponen } \\
\text { yang Diuji }\end{array}$ & Skenario Uji & Ket \\
\hline \multirow{5}{*}{4.} & Menu & Menginputkan Data dan & \\
\hline & Pengolahan & Menekan Tombol Hasil & Berhasil \\
\hline & Data & Tahap 1 & \\
\hline & & $\begin{array}{l}\text { Menekan Tombol Tanda } \\
\text { Panah }\end{array}$ & Berhasil \\
\hline & & Menekan Tombol Back & Berhasil \\
\hline
\end{tabular}

Berdasarkan pada tabel 7, didapat kesimpulan bahwa aplikasi dapat berjalan dengan baik, di mana fungsi dan fitur pada setiap menu maupun objek dapat berfungsi sesuai dengan tujuan perancangan.

\section{B. Pengujian Akurasi}

Uji akurasi dilakukan dengan perhitungan aplikasi dan perhitungan manual menggunakan kalkulator bertujuan untuk melihat hasil perhitungan pada aplikasi apakah terdapat kesalahan atau sudah tepat. Pada pengujian ini akan menguji kebenaran perhitungan terhadap hasil output kalor jenis. Pada pengujian ini dilakukan dengan menghitung nilai $\mathrm{Cb}$ untuk menentukan kalor jenis kalorimeter. Diketahui parameter sebagai berikut :

$$
\begin{aligned}
& \mathrm{m}_{\mathrm{k}}=92,5 \text { gram } \\
& \mathrm{m}_{\mathrm{k}+\mathrm{a}}=183 \text { gram } \\
& \mathrm{m}_{\mathrm{a}}=90,5 \text { gram } \\
& \mathrm{m}_{\mathrm{b}}=104,2 \text { gram } \\
& \mathrm{c}_{\mathrm{a}}=1 \mathrm{kal} / \mathrm{gr}^{\circ} \mathrm{C} \\
& \mathrm{c}_{\mathrm{k}}=0,217 \mathrm{kal} / \mathrm{gr}^{\circ} \mathrm{C} \\
& \mathrm{t}_{\mathrm{a} 1}=\mathrm{t}_{\mathrm{k}}=28^{\circ} \mathrm{C} \\
& \mathrm{t}_{\mathrm{b}}=74^{\circ} \mathrm{C} \\
& \mathrm{t}_{\mathrm{c}}=34^{\circ} \mathrm{C}
\end{aligned}
$$

Berikut ini adalah hasil pengujian akurasi:

Tabel 8. Pengujian Akurasi

\begin{tabular}{ccc}
\hline $\begin{array}{c}\text { Perhitungan } \\
\text { Dengan }\end{array}$ & $\mathbf{C b}$ & $\begin{array}{c}\text { Kalor Jenis } \\
\text { Zat }\end{array}$ \\
\hline Aplikasi & $0,1591735 \mathrm{kal} / \mathrm{gr}^{\circ} \mathrm{C}$ & Kaca \\
Kalkulator & $0,159173 \mathrm{kal} / \mathrm{gr}^{0} \mathrm{C}$ & Kaca \\
\hline
\end{tabular}

Dapat dilihat pada tabel 8 terdapat perbedaan pada hasil $\mathrm{Cb}$ yang dihitung menggunakan aplikasi dengan kalkulator sebagai alat bantu hitung yang memiliki nilai error 0,0000005 . Hal ini dikarenakan pada kalkulator terdapat pembulatan bilangan.

\begin{tabular}{|c|c|c|c|c|}
\hline No & Pertanyaan & $\begin{array}{c}\text { Jawaban } \\
\text { Responden }\end{array}$ & $(\mathrm{Y})$ & Hasil \\
\hline \multirow{4}{*}{1.} & & SS & \multirow{4}{*}{$82,5 \%$} & \multirow{4}{*}{ SS } \\
\hline & Mengetahui tentang & $S$ & & \\
\hline & Augmented Reality? & TS & & \\
\hline & & STS & & \\
\hline \multirow{4}{*}{2.} & Mengetahui tentang & SS & \multirow{4}{*}{$82,5 \%$} & \multirow{4}{*}{ SS } \\
\hline & aplikasi Augmented & $S$ & & \\
\hline & Reality untuk & TS & & \\
\hline & pembelajaran & STS & & \\
\hline \multirow{3}{*}{3.} & Aplikasi & SS & \multirow{7}{*}{$76,25 \%$} & \multirow{7}{*}{ SS } \\
\hline & Kalorimeter AR ini & $S$ & & \\
\hline & dapat & TS & & \\
\hline \multirow{8}{*}{4.} & $\begin{array}{l}\text { mempermudah } \\
\text { praktikan dalam }\end{array}$ & & & \\
\hline & memahami & STS & & \\
\hline & praktikum & & & \\
\hline & kalorimeter & & & \\
\hline & Aplikasi & SS & \multirow{4}{*}{$83,75 \%$} & \multirow{4}{*}{ SS } \\
\hline & Kalorimeter AR ini & $S$ & & \\
\hline & $\begin{array}{l}\text { dapat menjadi } \\
\text { media pembelajaran }\end{array}$ & TS & & \\
\hline & $\begin{array}{ll}\text { untuk } & \text { para } \\
\text { praktikan } & \end{array}$ & STS & & \\
\hline \multirow{3}{*}{5.} & Aplikasi $\quad$ vang & SS & \multirow{3}{*}{$75 \%$} & \multirow{3}{*}{ SS } \\
\hline & dibuat sesuai & $S$ & & \\
\hline & dengan kebutuhan & $\begin{array}{l}\text { TS } \\
\text { STS }\end{array}$ & & \\
\hline \multirow{4}{*}{6} & & SS & \multirow{3}{*}{$61,25 \%$} & \multirow{3}{*}{ S } \\
\hline & $\begin{array}{l}\text { Tampilan aplikasi } \\
\text { menarik }\end{array}$ & $\begin{array}{c}\text { S } \\
\text { TS }\end{array}$ & & \\
\hline & & STS & & \\
\hline & & SS & \multirow{3}{*}{$72,25 \%$} & \multirow{3}{*}{$S$} \\
\hline \multirow[t]{2}{*}{7.} & Aplikasi ini mudah & $\begin{array}{c}S \\
T S\end{array}$ & & \\
\hline & & $\begin{array}{l}15 \\
\text { STS }\end{array}$ & & \\
\hline \multirow{5}{*}{8.} & Dengan adanya fitur & SS & \multirow{5}{*}{$80 \%$} & \multirow{5}{*}{ SS } \\
\hline & Pengolahan data & $S$ & & \\
\hline & mempermudah & TS & & \\
\hline & praktikan dalam & & & \\
\hline & $\begin{array}{l}\text { mengolah data } \\
\text { praktikum }\end{array}$ & STS & & \\
\hline
\end{tabular}

\section{Pengujian Beta}

Kuesioner ini terdiri dari 8 (delapan) pertanyaan dan diisi oleh 20 responden yaitu praktikan yang telah mengambil mata kuliah fisika dasar. Sebanyak $70 \%$ responden berumur dibawah 22 tahun, dan $30 \%$ atas 21 tahun serta $90 \%$ berjenis kelamin laki-laki, dan $10 \%$ adalah perempuan.
Tabel 9. Hasil Pengujian Beta

Berdasarkan pada tabel 9, hasil pengujian Beta menunjukkan bahwa dalam penggunaan aplikasi Kalorimeter AR dapat mempermudah praktikan untuk memahami suatu materi kalorimeter dengan skor indeks 76,25\% dengan kategori indeks skor "Sangat (Setuju, Baik, Suka)". Kemudian, mempermudah praktikan dalam mengolah data praktikum dengan skor indeks $80 \%$ dengan kategori indeks skor "Sangat (Setuju, Baik, Suka)".

\section{Pengujian Marker}

Pengujian aplikasi Augmented Reality ini menggunakan beberapa parameter. Parameter tersebut adalah, intensitas cahaya, jarak penempatan marker, batas kemiringan, dan luas permukaan. 
A. Intensitas Cahaya

Pengujian ini dilakukan di dalam ruangan dan luar ruangan menggunakan aplikasi light meter untuk mengukur cahaya, didapat hasil bahwa intensitas cahaya cerah akan lebih cepat terdeteksi dari pada intensitas cahaya yang rendah/redup.

\section{B. Jarak Penempatan Marker}

Dalam hal ini pengujian dilakukan pada jarak 5 $\mathrm{cm}, 10 \mathrm{~cm}, 20 \mathrm{~cm}, 30 \mathrm{~cm}, 40 \mathrm{~cm}, 50 \mathrm{~cm}, 60 \mathrm{~cm}, 70$ $\mathrm{cm}, 80 \mathrm{~cm}$ dari kamera, didapat hasil bahwa pendeteksian marker dapat bekerja ketika jarak kamera dengan marker berada pada rentang jarak $10 \mathrm{~cm}-70 \mathrm{~cm}$ dengan intensitas cahaya 52 - 9786 lux.

\section{Pengujian Marker Batas Kemiringan}

Pada pengujian ini menggunakan sudut $0^{0}, 15^{0}$, $30^{\circ}, 45^{\circ}, 60^{\circ}, 75^{\circ}$, dan jarak kamera terhadap marker sejauh $20 \mathrm{~cm}$, didapat hasil bahwa toleransi kemiringan pembacaan marker hanya berkisar pada $0^{\circ}$ hingga $60^{\circ}$

\section{Pengujian Marker Luas Permukaan}

Dalam pengujian ini area image target dihalangi dengan persentase $25 \%$, 50\%, dan $75 \%$ dengan jarak kamera ke marker sejauh $20 \mathrm{~cm}$. Disimpulkan bahwa marker yang tertutupi lebih dari 50\% tidak dapat menampilkan objek 3D di atas marker.

\section{KESIMPULAN}

Berdasarkan hasil pengujian dari Aplikasi Teknologi Augmented Reality Untuk Tutorial Praktikum Kalorimeter Dan Penentuan Kalor Jenis Menggunakan Metode Fuzzy Mamdani yang telah dirancang, maka dapat ditarik kesimpulan bahwa aplikasi ini berhasil mengolah data praktikum untuk melakukan penentuan kalor jenis menggunakan metode fuzzy Mamdani, dan aplikasi dapat berjalan sesuai dengan yang diharapkan. Hal ini ditunjukan dengan persentase $76,25 \%$ dari hasil kuesioner kepada pengguna aplikasi dan $80 \%$ mempermudah praktikan dalam pemrosesan data praktikum. Dalam penerapan metode fuzzy mamdani pada penentuan kalor jenis mempunyai tingkat error sebesar 0,0000005. Kemudian pencahayaan yang baik dapat membantu kamera untuk menemukan titik tepi yang telah diregistrasikan pada database Vuforia dengan objek jarak pendeteksian berada pada jarak $10 \mathrm{~cm} 70 \mathrm{~cm}$ di antara sudut $0^{\circ}$ sampai dengan $60^{\circ}$ dengan $50 \%$ marker yang tidak terhalang sehingga dapat memunculkan objek 3D.

\section{DAFTAR PUSTAKA}

[1] Nurkholis, "Pendidikan Dalam Upaya Memajukan Teknologi," J. Kependidikan, vol. 1, no. 1, pp. 24-44, 2013.

[2] Y. Suryaningsih, "Pembelajaran Berbasis Praktikum Sebagai Sarana Siswa Untuk Berlatih Menerapkan Keterampilan Proses Sains Dalam Materi Biologi," J. Bio Educ., vol. 2, no. 2, pp. 49-57, 2017.

[3] M. Ishaq, Fisika Dasar, 2nd ed. Yogyakarta: Graha Ilmu, 2007.

[4] R. A. Ahmadi, J. Adler, and S. L. Ginting, "Teknologi Augmented Reality sebagai Media Pembelajaran Gerakan Shalat," Pros. Semin. Nas. Komput. dan Inform., pp. 179186, 2017.

[5] F. Zuli, "Rancang Bangun Augmented Dan Virtual Reality Menggunakan Algoritma Fast Sebagai Media Informasi 3D Di Universitas Satya Negara Indonesia," J. Algoritm. Log. dan Komputasi, vol. 1, no. 2, pp. 94-104, 2018, doi: 10.30813/jalu.v1i2.1373.

[6] S. L. B. Ginting and F. Sofyan, "Aplikasi Pengenalan Alat Musik Tradisional Indonesia Menggunakan Metode Based Marker Augmented Reality Berbasis Android," Maj. Ilm. UNIKOM, vol. 15, no. 2, pp. 139-154, 2017, doi: 10.1021/ja00532a011.

[7] B. Arifitama, Panduan Mudah Membuah Augmented Reality. Jakarta: ANDI, 2017.

[8] A. Katiyar, K. Kalra, and C. Garg, "Marker Based Augmented Reality," Adv. Comput. Sci. Inf. Technol., vol. 2, no. 5, pp. 441-445, 2015.

[9] S. Supatmi, R. Hou, and I. D. Sumitra, "Study of Hybrid Neurofuzzy Inference System for Forecasting Flood Event Vulnerability in Indonesia," Comput. Intell. Neurosci., vol. 2019, 2019, doi: 10.1155/2019/6203510.

[10] H. P. S Kusumadewi, Aplikasi Logika Fuzzy untuk Pendukung Keputusan. Yogyakarta: Graha Ilmu, 2010.

[11] S. Setiawardhana, S. Wasista, and A. Y. Ardiansyah, “Aplikasi Augmented Reality Untuk Pengenalan Perangkat Jaringan Komputer Berbasis Android Sebagai Media Pembelajaran Interaktif," Link, vol. 24, no. 1, pp. 28-35, 2016, doi: 10.31090/link.v24i1.10.

[12] I. D. Sumitra and S. Supatmi, "Mamdani Fuzzy Inference System using Three Parameters for Flood Disaster Forecasting in Bandung region," IOP Conf. Ser. Mater. Sci. Eng., vol. 662, no. 4, pp. 1-9, 2019, doi: 10.1088/1757-899X/662/4/042008. 
[13] F. Zulham Adami and C. Budihartanti, “Penerapan Teknologi Augmented Reality Pada Media Pembelajaran Sistem Pencernaan Berbasis Android," Tek. Komput. AMIK BSI, vol. 11, no. 1, pp. 122131, 2016.

[14] A. Wiharto and C. Budihartanti, "Aplikasi Mobile Augmented Reality Sebagai Media Pembelajaran Pengenalan Hardware
Komputer Berbasis Android," J. PROSISKO, vol. 4, no. 2, pp. 17-24, 2017.

[15] E. Rusnandi, H. Sujadi, and E. Fibriyany Noer Fauzyah, "Implementasi Augmented Reality (AR) pada Pengembangan Media Pembelajaran Pemodelan Bangun Ruang 3D untuk Siswa Sekolah Dasar," Infotech J., vol. 1, no. 2, pp. 24-31, 2015. 